\title{
2'3'-Dideoxycytidine-induced Thymic Lymphoma Correlates with Species-specific Suppression of a Subpopulation of Primitive Hematopoietic Progenitor Cells in Mouse but Not Rat or Human Bone Marrow
}

\author{
Richard D. Irons, ${ }^{\star \$}$ Anh T. Le," David B. Som, * and Wayne S. Stillman * \\ ${ }^{*}$ Molecular Toxicology and Environmental Health Sciences, School of Pharmacy; ${ }^{\ddagger}$ Department of Pathology, School of Medicine; and \\ ${ }^{8}$ Cancer Center, University of Colorado Health Sciences Center, Denver, Colorado 80262; and "Division of Biology and Biomedical \\ Sciences, Washington University School of Medicine, St. Louis, Missouri 63110
}

\begin{abstract}
The nucleoside analogue, $2^{\prime}, 3^{\prime}$-dideoxycytidine (ddC), is a potent inhibitor of HIV replication, and AIDS patients receiving ddC experience clinical improvement without significant hematologic toxicity. Repeated ddC administration $(1,000 \mathrm{mg} / \mathrm{kg}$ per day) for 13 wk produces an increased incidence of thymic lymphoma in B6C3F1 mice. Previous studies reveal a common link between chemically induced and genetically associated models of mouse thymic lymphoma that involves a defect in a subpopulation of primitive hematopoietic progenitor cells. This defect is characterized by suppression of a subpopulation of IL-3-responsive cells and ablation of stem cell factor synergy with GM-CSF. The present study was undertaken to ascertain whether ddC produces the same pattern of bone marrow toxicity in mice, and whether this effect is observed in rat and human bone marrow. ddC exposure in vivo and in vitro produced a select suppression of murine CFU identical to that previously described for other models of mouse thymic lymphoma. In contrast, this selective CFU suppression was not observed in rat and human bone marrow or in CD34+ cells. These studies suggest that the mouse may not be a good predictive model for ddC hematotoxicity in humans and that susceptibility to the development of thymic lymphoma may be unique to the mouse. (J. Clin. Invest. 1995. 95:2777-2782.) Key words: antiviral agents - stem cells, hematopoietic • cytokines $\cdot$ thymoma $\cdot$ colony-forming units assay
\end{abstract}

\section{Introduction}

The nucleoside analogue, $2^{\prime}, 3^{\prime}$-dideoxycytidine $(\mathrm{ddC})^{1}$ is approved for treatment of HIV positive patients. ddC interferes with HIV replication by inhibiting reverse transcriptase $(1,2)$, and AIDS patients receiving ddC experience clinical improve-

Address correspondence to Dr. Richard Irons, University of Colorado Health Sciences Center, MTEHS Program, Campus Box C-235, 4200 E. 9th Ave., Denver, CO 80262. Phone: 303-270-7170; FAX: 303-2707223.

Received for publication 21 December 1994.

1. Abbreviations used in this paper: BM, bone marrow; ddC, 2',3'dideoxycytidine; HPC, hematopoietic progenitor cells; r, recombinant; SCF, stem cell factor; TL, thymic lymphoma/leukemia.

J. Clin. Invest.

(C) The American Society for Clinical Investigation, Inc.

0021-9738/95/06/2777/06 \$2.00

Volume 95, June 1995, 2777-2782 ment with less hematologic toxicity than associated with the use of zidovudine ( 3 '-azido-2',3'-dideoxythymidine) (AZT) $(3,4)$. A treatment-related increase in lymphoma has not been reported. However, in two separate studies, high dose administration of ddC, $1,000 \mathrm{mg} / \mathrm{kg}$ per day, for three months to mice by gavage resulted in a significant incidence of thymic lymphoma/leukemia (TL), anemia, and thymic atrophy (National Toxicology Program. 1993. Subchronic toxicity study of 2',3'-dideoxycytidine (ddC) in female B6C3F1 mice. Southern Research Institute Study A19-SCM-3) (5).

The pathogenesis of TL is virtually identical in radiation, chemical and genetic mouse models, invoking a paradigm that includes the requirement for a "preleukemic event" in bone marrow (BM), accompanied by a macrocytic anemia, thymic hypoplasia and the development of lymphoma in the thymus (5-12).

We have previously identified a distinct subpopulation of stem cell factor (SCF) -dependent/IL-3-responsive hematopoietic progenitor cells (HPC) in the mouse that is uniquely susceptible to functional suppression by murine leukemogens, such as 1,3-butadiene (13) and $\gamma$-irradiation (Irons, R. D., S. C. Lee, and W. S. Stillman, manuscript in preparation). This subpopulation of HPC is identical to that constitutively missing in mice bearing W or S1 mutations that spontaneously develop TL (13). Mice with mutations at the Sl and W locus demonstrate complementary defects for SCF, Sl mice are deficient in SCF (14), and W mice lack a functional analogous receptor, C-kit $(15,16)$. Taken together, these results suggest that the genetic or functional suppression of this subpopulation of primitive hematopoietic cells represents the early bone marrow lesion common to chemical, radiation, and genetic models of murine TL leukemogenesis.

Herein, we examined whether ddC exposure in vivo and in vitro produces the same lesion as described above. Moreover, in order to determine if there are species-specific differences in susceptibility to ddC, we compared the effects of ddC on unpurified rat and unpurified and CD34-enriched human bone marrow cells. The results of these studies demonstrate that ddC targets the same population of primitive murine HPC as other murine leukemogens. In contrast, no selective suppression of clonogenic response is observed in rat or human bone marrow cells.

\section{Methods}

Reagents. ddC was obtained from Hoffmann-La Roche Inc. (Nutley, $\mathrm{NJ})$. Epoxybutene (3,4-epoxybutene) was purchased from Aldrich Chemical Co. (Milwaukee, WI). Murine recombinant (r)GM-CSF ( 5 $\left.\times 10^{7} \mathrm{U} / \mathrm{mg}\right)$, rSCF $\left(10^{5} \mathrm{U} / \mathrm{mg}\right)$, and $\mathrm{rIL}-3\left(5 \times 10^{5} \mathrm{U} / \mathrm{mg}\right)$ and human rGM-CSF $\left(1.25 \times 10^{7} \mathrm{U} / \mathrm{mg}\right), \mathrm{rSCF}\left(10^{5} \mathrm{U} / \mathrm{mg}\right)$, and rIL-3 $\left(2 \times 10^{7} \mathrm{U} / \mathrm{mg}\right.$ ) were generous gifts from Immunex (Seattle, WA). 

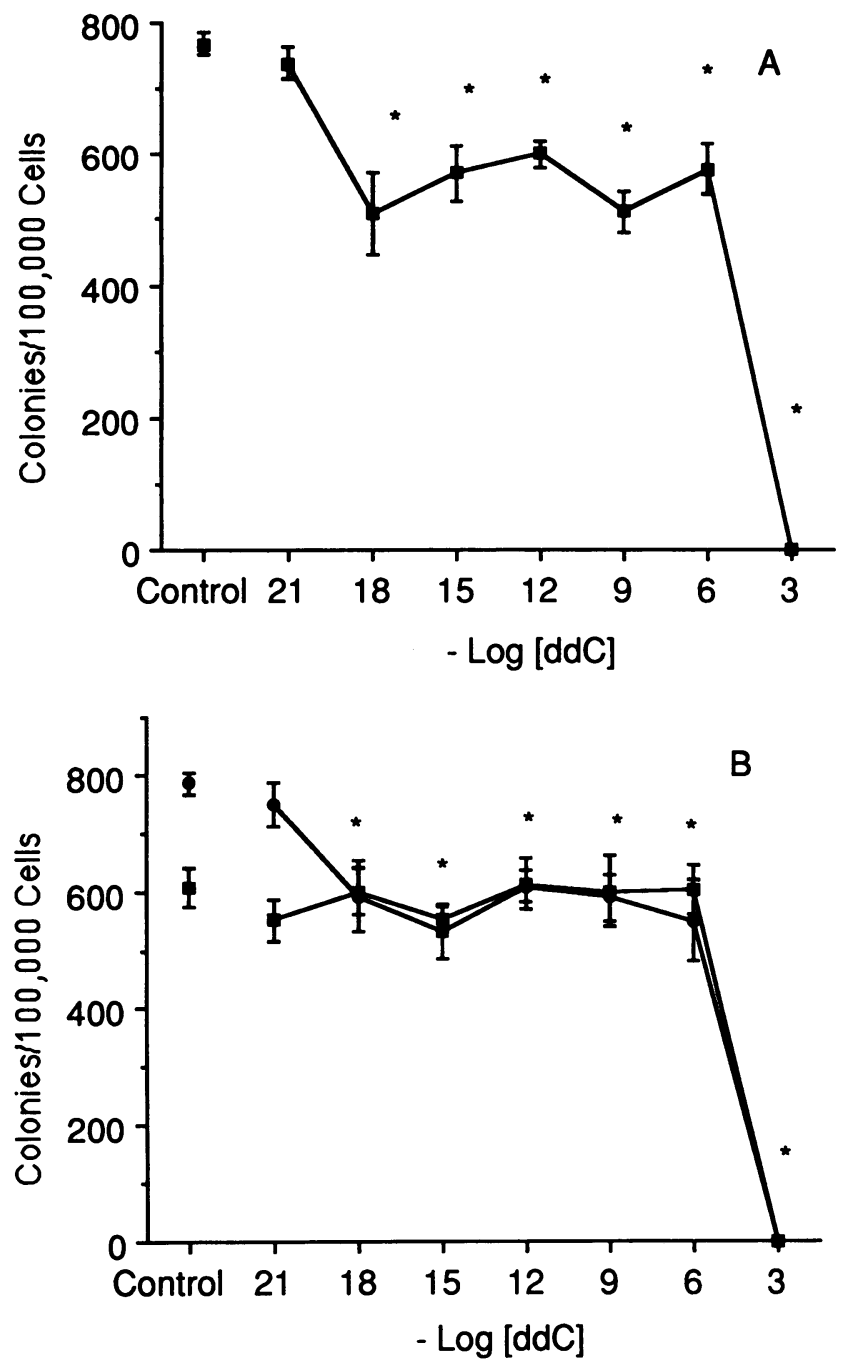

Figure 1. Effects of ddC on $(A)$ rIL-3 and $(B)$ rGM-CSF-stimulated colony formation of $\mathrm{BM}$ from $\mathrm{B} 6 \mathrm{C} 3 \mathrm{~F} 1$ mice with or without $\mathrm{rSCF} .(A)$ (घ) IL-3 (1 ng/ml); (B) (घ) rGM-CSF (2 ng/ml); (•) rGM-CSF (2 $\mathrm{ng} / \mathrm{ml})+\mathrm{rSCF}(10 \mathrm{ng} / \mathrm{ml})$. Error bars indicate 1 SEM for five cultures and are omitted when they are smaller than the symbol. * Significant decrease compared with controls not cultured with ddC $(P \leq 0.05)$.

Modified Iscove's medium, L-glutamine, penicillin/streptomycin solution and PBS were purchased from GIBCO BRL, (Gaithersburg, MD). FBS was supplied by Gemini Bioproducts (Calabasas, CA). Lympholyte-M was obtained from Accurate Scientific (Westbury, NY). Histopaque-1077, methyl cellulose, BSA, and 2-mercaptoethanol were purchased from Sigma Chemical Company (St. Louis, MO). The MiniMACS separation system and CD34 cell isolation kit were supplied by Miltenyi Biotech Inc. (Sunnyvale, CA). FITC-conjugated anti-CD34 (HPCA-2) was purchased from Becton Dickinson (San Jose, CA).

Animals. 4-wk-old male C57BL/6J, B6C3F1, $\mathrm{WBB}^{2} \mathrm{~F}_{1} / \mathrm{J}-\mathrm{W} / \mathrm{W}^{v}$ and $\mathrm{WCB} \mathrm{F}_{1} / \mathrm{J}-\mathrm{Sl} / \mathrm{Sl}^{\mathrm{d}}$ mice were obtained from The Jackson Laboratory (Bar Harbor, ME). CD rats and CD-1 mice were obtained from Charles River Laboratories (Wilmington, MA). Animals were acclimated for 2 wk before use and were housed 10 to a cage in sterile chambers with filter tops. Mice were allowed autoclaved food (3000, Agway, Syracuse, NY) and sterilized water, ad libitum. All procedures performed on mice were approved by the University of Colorado Health Sciences Center's Animal Care and Use Committee.

Human bone marrow. Human BM was obtained with informed con-

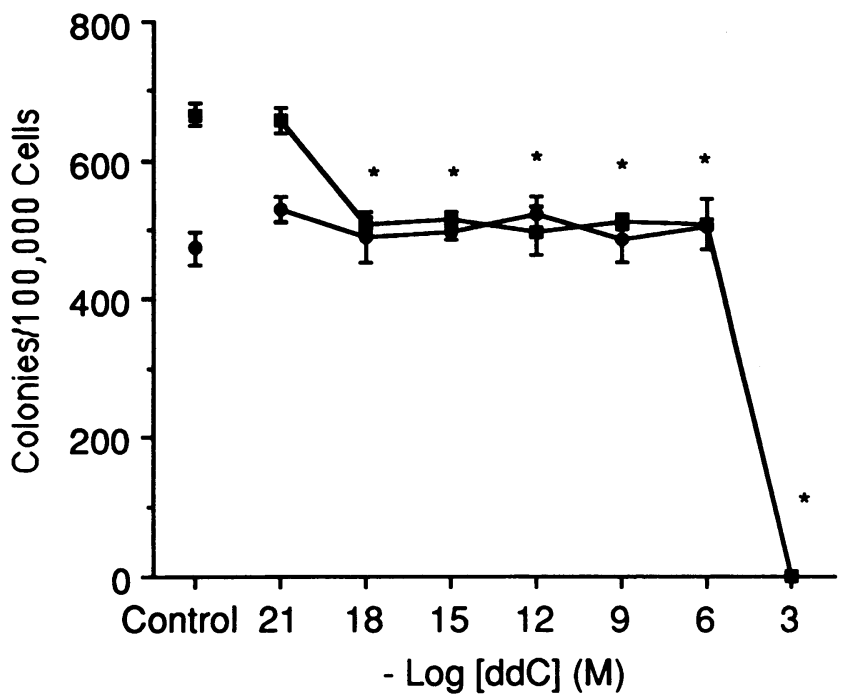

Figure 2. Recombinant IL-3 $(1 \mathrm{ng} / \mathrm{ml})$ stimulated colony formation of C57BL/6 BM pretreated with $(\bullet)$ epoxybutene or ( $\square$ ) vehicle (PBS) and cultured with ddC. Error bars indicate 1 SEM for five cultures and are omitted when they are smaller than the symbol. * Significant decrease compared with controls not cultured with ddC $(P \leq 0.05)$.

sent from normal adult volunteers by aspiration from the posterior iliac crest. These studies were conducted under a protocol approved by the University of Colorado Health Sciences Center's Internal Review Board.

Mouse/rat bone marrow cell preparation. Mononuclear nonadherent bone marrow cells were harvested from femora as previously described (13). Briefly, animals were killed by cervical dislocation and bone marrow was flushed from femora with PBS containing $1 \%$ BSA using a 5-ml syringe with a 22-gauge needle. A single cell suspension was obtained using a pasteur pipette, which was then purified over Lympholyte-M. The recovered buffy layer was removed and washed twice in PBS/BSA. Nonadherent cells were obtained by incubating the cells at $2 \times 10^{6} / \mathrm{ml}$ in culture flasks for $1 \mathrm{~h}$ at $37^{\circ} \mathrm{C}$ in PBS/BSA.

Human bone marrow cell preparation. Mononuclear cells were iso-

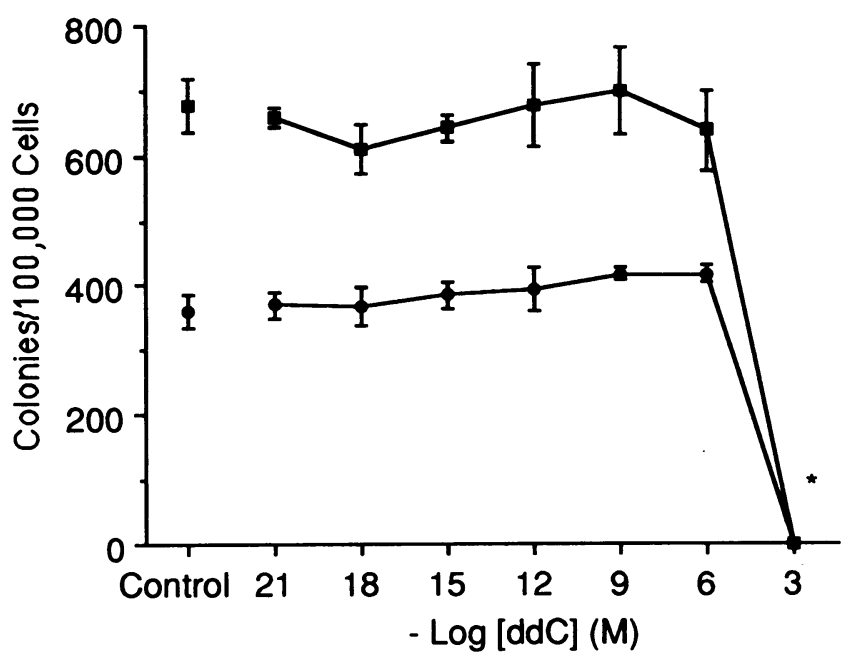

Figure 3. Effects of ddC on rIL-3 $(1 \mathrm{ng} / \mathrm{ml})$ stimulated CFU of BM from $(\square) \mathrm{W} / \mathrm{W}^{\mathrm{v}}$ and $(\bullet) \mathrm{Sl} / \mathrm{Sl}^{\mathrm{d}}$ mice. Error bars indicate $1 \mathrm{SEM}$ for five cultures and are omitted when they are smaller than the symbol. * Significant decrease compared with controls not cultured with ddC $(P \leq 0.05)$. 

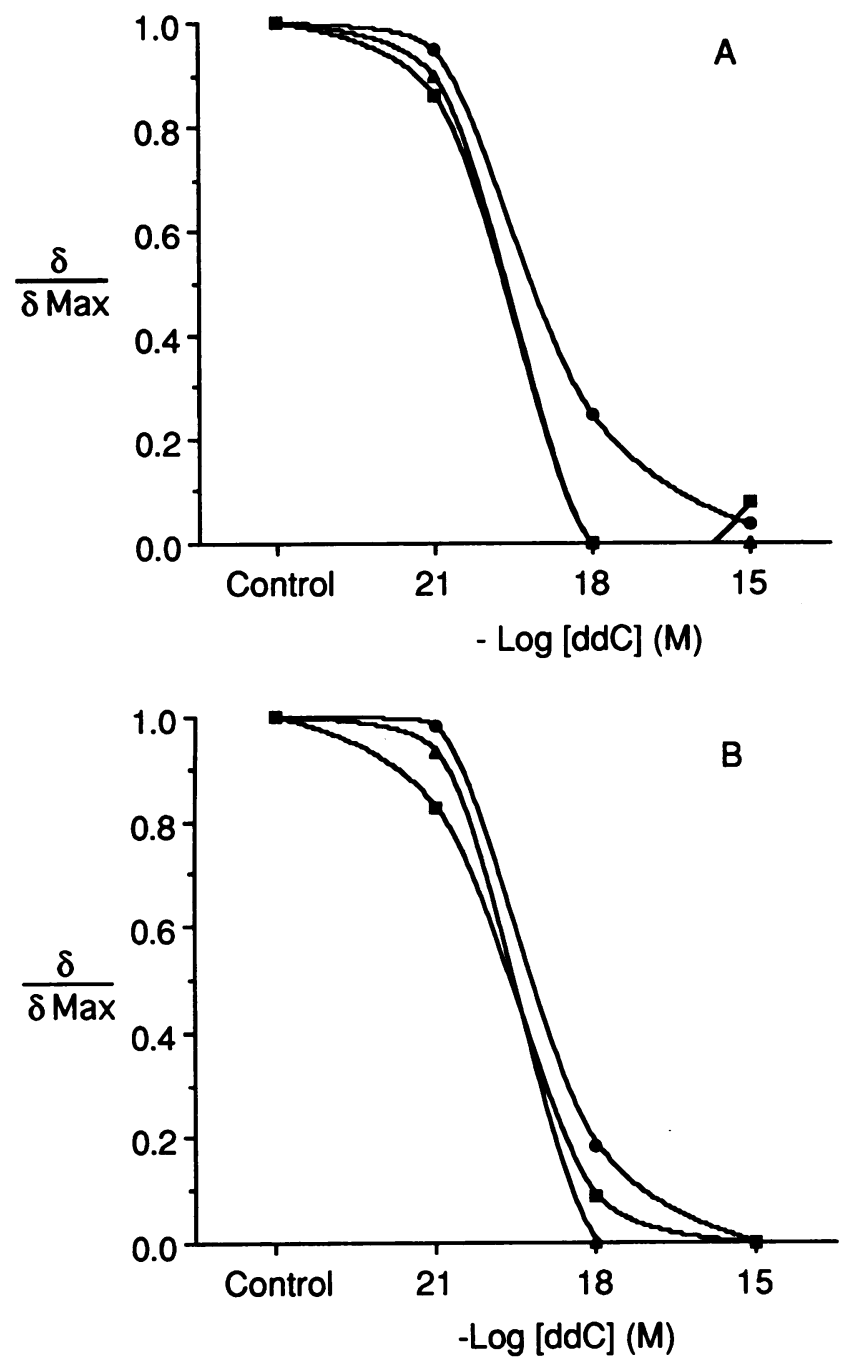

Figure 4. Comparison of the effects of ddC on $(A)$ rlL-3 and $(B)$ rGMCSF+ rSCF stimulated CFU of bone marrow cells from ( $\square$ ) B6C3F1, (•) C57BL/6, and ( $\triangle$ ) CD-1 mice. The data, normalized as fractional suppression $(\delta / \delta \mathrm{Max})$ of clonogenic response, is derived from individual experiments with bone marrow cells from each strain of mouse, five cultures per each concentration.

lated by using Histopaque-1077 per manufacturer's instructions. Nonadherent cells were obtained by incubating the cells for $1 \mathrm{~h}$ at $37^{\circ} \mathrm{C}$ in PBS/BSA. CD34+ cells were purified from the mononuclear cells by using the MiniMACS purification system according to manufacturer's instructions. The CD34 purity was determined by labeling the cells with FITC-conjugated anti-CD34 mAb (HPCA-2) specific for a CD34 epitope distinct from that used in the purification process (QBEND-10) followed by flow cytometry analysis (Epics 752; Coulter Electronics, Hialeah, FL). The percentage CD34+ was $>91 \%$ for each experiment.

Drug exposures. In vitro: ddC was dissolved in Iscove's medium containing $10 \%$ FBS, titered and added to methyl cellulose before the addition of cells. For experiments with epoxybutene pretreatment, cells were incubated with PBS or epoxybutene dissolved in PBS for $30 \mathrm{~min}$ at $37^{\circ} \mathrm{C}$, washed in Iscove's containing $10 \%$ FBS and used in the CFU assay. In vivo: mice were administered a single dose of ddC dissolved in distilled water containing $0.5 \%$ methyl cellulose by gavage, sacrificed $2 \mathrm{~h}$ later, and their bone marrow used in the CFU assay.

CFU assay. The CFU assay was performed as previously described (13). Briefly, bone marrow cells were plated in 35-mm culture dishes at a concentration of 1 to $5 \times 10^{4} \mathrm{cells} / \mathrm{ml}$ in $1 \mathrm{ml}$ of modified Iscove's

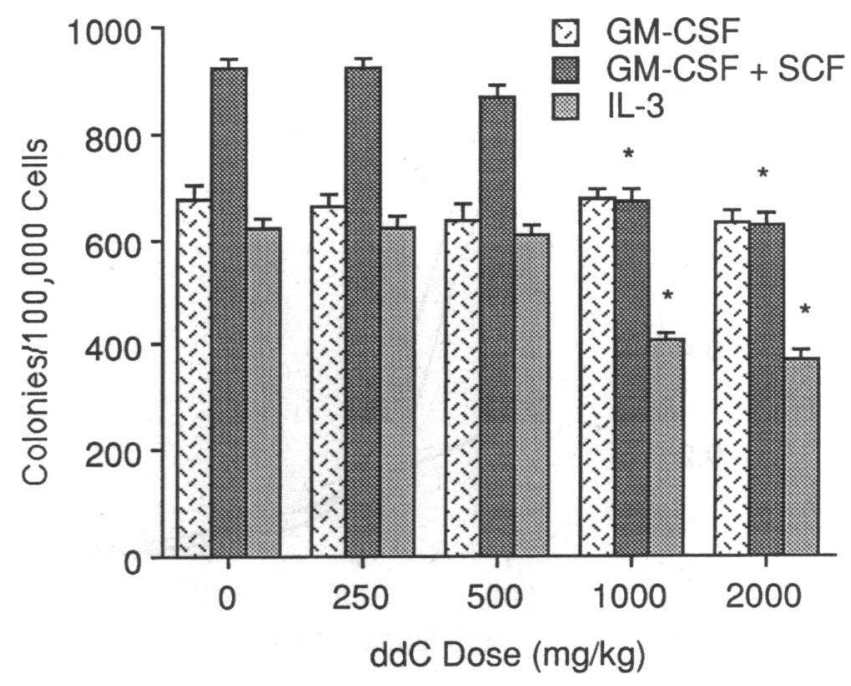

Figure 5. Recombinant rGM-CSF ( $2 \mathrm{ng} / \mathrm{ml})$ with or without rSCF (2 $\mathrm{ng} / \mathrm{ml})$ and IL-3 $(1 \mathrm{ng} / \mathrm{ml})$ stimulated CFU of BM from B6C3F1 mice killed $2 \mathrm{~h}$ after single administration of ddC by gavage. Error bars indicate 1 SEM for five cultures from each of three animals. * Significant decrease compared with controls given vehicle only $(P \leq 0.05)$.

medium containing $10-20 \%$ FBS, $100 \mathrm{mg} / \mathrm{ml}$ streptomycin, $100 \mathrm{U} / \mathrm{ml}$ penicillin, $2 \mathrm{mM}$ L-glutamine, $50 \mathrm{mM}$ 2-mercaptoethanol, $1.2 \%$ (wt/ vol) methyl cellulose, and recombinant cytokines. Each cytokine was used at concentrations experimentally determined to produce maximal colony formation. All cultures were maintained at $37^{\circ} \mathrm{C}$ in $5 \% \mathrm{CO}_{2}$. Colonies consisting of 30 or more cells were scored on days 8 and 14 for mouse and human BM, respectively.

Statistical analysis. Five plates were scored for each in vitro treatment group or individual animal and results expressed as the mean \pm 1 SEM. For in vivo studies three animals were examined per dose (five cultures per animal). Significant differences $(P \leq 0.05)$ between pretreated and control groups were determined using the Student's $t$ test. For studies using human cells, bone marrow from each volunteer was treated as a separate experiment with five plates scored and results expressed as the mean \pm 1 SEM. All statistics were calculated using Excel 4.0 (Microsoft Corp., Redmond, WA).

\section{Results}

ddC cultured with B6C3F1, C57BL/6, or CD-1 murine bone marrow cells in vitro produces an identical suppression of clonogenic response as described for other mouse leukemogens. B6C3F1 mouse bone marrow cells cultured with ddC in vitro results in a suppression of clonogenic response in a subpopulation of IL-3 responsive cells (Fig. $1 A$ ), and abrogation of SCF synergy with GM-CSF (Fig. $1 B$ ). The identical suppression of CFU is observed when murine HPC are pretreated with epoxybutene, a metabolite of the prototype murine leukemogen, 1,3-butadiene (13). Murine BM pretreated with epoxybutene is completely unresponsive to the effects of $\mathrm{ddC}$, confirming that ddC targets the same subpopulation of clonogenic cells (Fig. 2). Moreover, ddC pretreatment of bone marrow from $\mathrm{W} / \mathrm{W}^{\mathrm{v}}$ and $\mathrm{Sl} / \mathrm{Sl}^{\mathrm{d}}$ mice does not suppress IL-3 (Fig. 3) or alter GM-CSF response (data not shown), indicating that the subpopulation of cells targeted by $\mathrm{ddC}$ is the same subpopulation of primitive hematopoietic cells previously demonstrated to be absent in these genetic models (13).

We also compared the relative susceptibility of HPC to the 

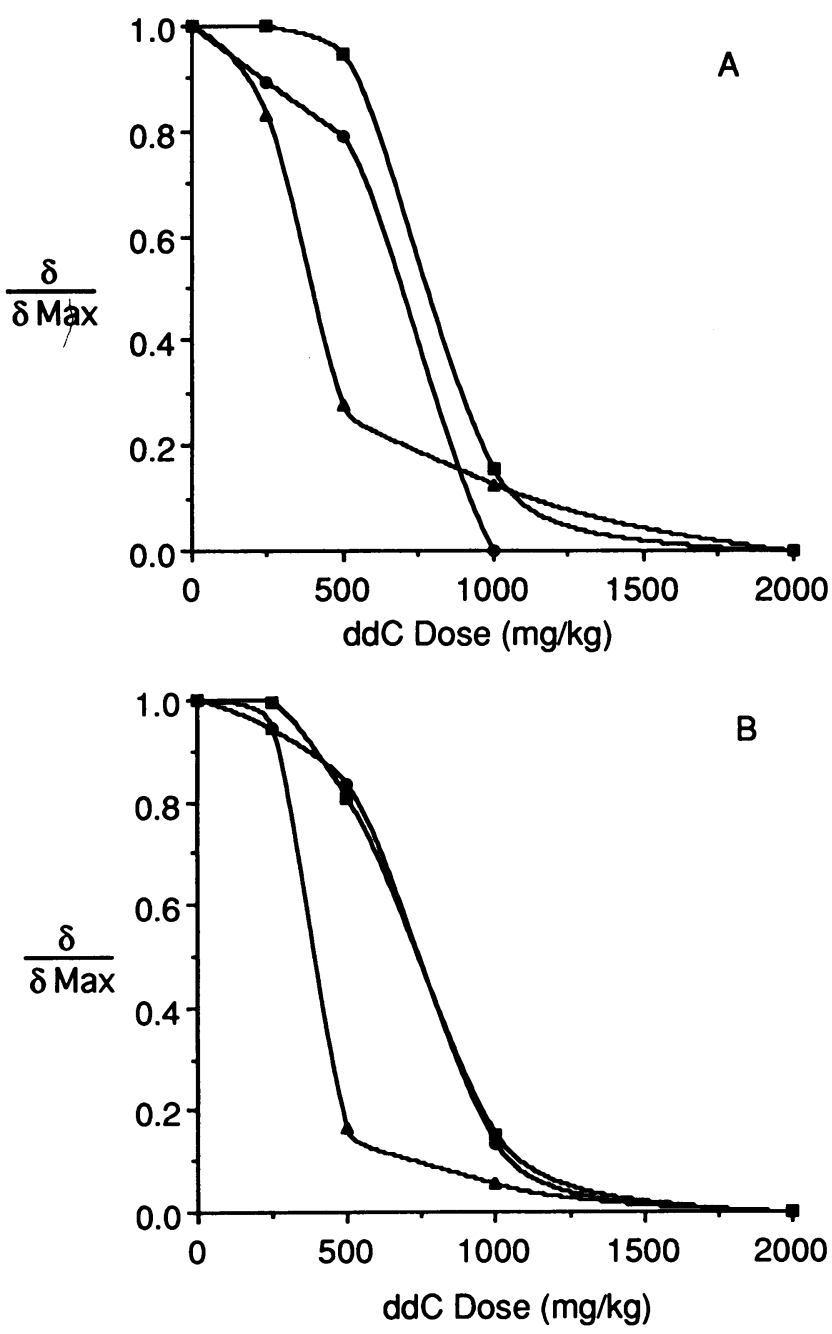

Figure 6. Comparison of $(A)$ rIL-3 and $(B)$ rGM-CSF with rSCF stimulated colony formation of BM from $(\bullet) \mathrm{B} 6 \mathrm{C} 3 \mathrm{~F} 1,(\bullet) \mathrm{C} 57 \mathrm{BL} / 6$, and ( $\triangle$ ) CD-1 mice killed $2 \mathrm{~h}$ after single administration of ddC by gavage. The data, normalized as fractional suppression $(\delta / \delta \mathrm{Max})$ of clonogenic response, is derived from individual experiments conducted for each strain of mouse. Three animals ( $n=5$ cultures per animal) were examined for each dose.

suppressive effects of ddC in vitro using BM from C57BL/6 and CD-1 mice. Fig. 4 summarizes the effects of ddC exposure in vitro for the three different strains of mice. Specific suppression of CFU was observed in each strain at $10^{-18} \mathrm{M}$ ddC. Generalized nonspecific cytotoxicity was evident in each strain at $10^{-3} \mathrm{M}$ ddC (Fig. 1, data not shown for C57BL/6 and CD1 mice)

Administration of ddC to mice by gavage produces the same suppression of clonogenic response observed for $d d C$ in vitro. $\mathrm{B} 6 \mathrm{C} 3 \mathrm{~F} 1$ mice were given various doses of $\mathrm{ddC}$ by gavage and BM assayed $2 \mathrm{~h}$ later for IL-3, GM-CSF, and GM-CSF/SCF stimulated clonogenic response. The identical pattern of suppression that characterizes in vitro exposure of $\mathrm{BM}$ to $\mathrm{ddC}$ and other murine leukemogens is observed in the 1,000 and 2,000 $\mathrm{mg} / \mathrm{kg}$ ddC dose groups (Fig. 5). Strain differences in susceptibility to $\mathrm{ddC}$ were observed in vivo, with $\mathrm{CD}-1$ mice demonstrating increased sensitivity over C57BL/6 and B6C3F1 mice (Fig. 6). Because strain differences are not observed in vitro,

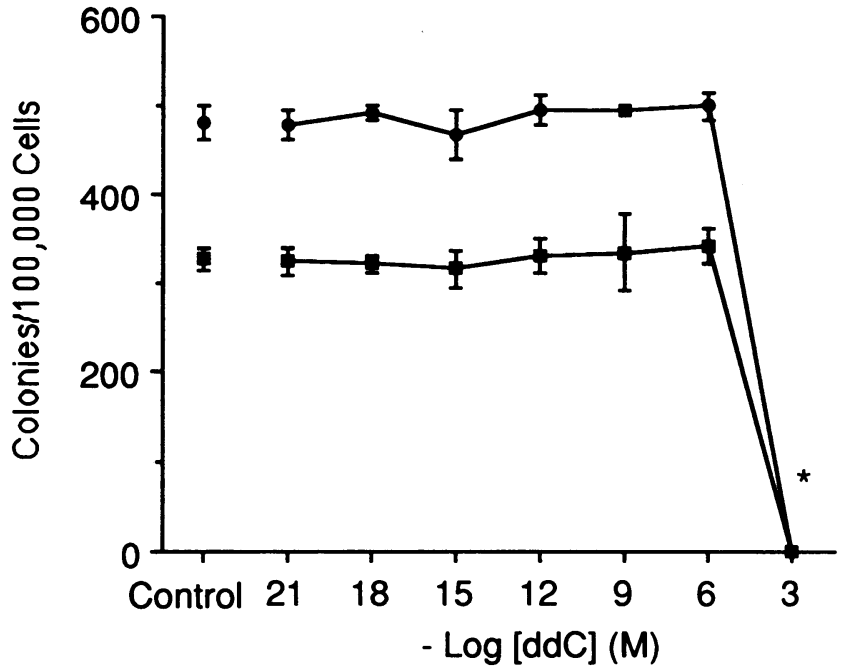

Figure 7. Effects of ddC on rGM-CSF stimulated colony formation of BM from CD-1 rats with or without rSCF. (匹) Murine rGM-CSF ( 5 $\mathrm{ng} / \mathrm{ml})$; (•) Murine rGM-CSF $(5 \mathrm{ng} / \mathrm{ml})+$ murine $\mathrm{rSCF}(10 \mathrm{ng} / \mathrm{ml})$. Error bars indicate 1 SEM for five cultures and are omitted when they are smaller than the symbol. * Significant decrease compared with controls not cultured with ddC $(P \leq 0.05)$.

it is likely that they are related to the pharmacodynamics of ddC and not intrinsic differences in target cell-specific metabolism or susceptibility.

ddC cultured with $C D$ rat bone marrow cells in vitro does not affect $C F U$ response. In contrast to mice, rats are resistant to the development of lymphoma/leukemia, and do not develop the disease following chronic exposure to butadiene $(17,18)$ or radiation (19). We were precluded from a direct examination of IL-3 response in rats due to the unavailability of a functional cytokine for that species. However, identical to results previously obtained with 1,3-butadiene (Irons, R. D., D. B. Colagiovanni, and W. S. Stillman, manuscript in preparation), ddC pretreatment does not suppress SCF synergism with GM-CSF in rat bone marrow cells (Fig. 7).

ddC cultured with nonadherent human bone marrow or CD34+ cells in vitro produces no selective suppression of clonogenic response. The $\mathrm{CD} 34+$ cell population contains all clonogenic cells identified in human BM, including both long term and short term repopulating cells (20), and is markedly enriched for primitive HPC that are responsive to SCF synergism with GM-CSF. This corresponds to the cell population targeted by ddC in mouse bone marrow. A total of 11 experiments were conducted using human bone marrow cells; 4 used mononuclear nonadherent BM cells and 7 used CD34+ BM cells. The BM donor pool was comprised of 6 females and 5 males with a mean age of 31 ( $\pm 5.95 \mathrm{SD})$. A representative experiment with CD34+ BM cells is shown in Fig. 8, with all the data from these experiments presented in Fig. 9. ddC pretreatment does not result in selective suppression of SCF-dependent/IL-3 responsive HPC in either nonadherent or CD34+ enriched human BM cells. Nonspecific cytotoxicity is consistently observed in nonadherent cells from mice, rats and humans incubated with $\mathrm{mM}$ concentrations of ddC. However, CD34+ cells exhibit nonspecific suppression of clonogenic response at micromolar concentrations of ddC. Increased susceptibility to nonspecific cytotoxicity for CD34+ cells relative to nonadherent BM cells sug- 

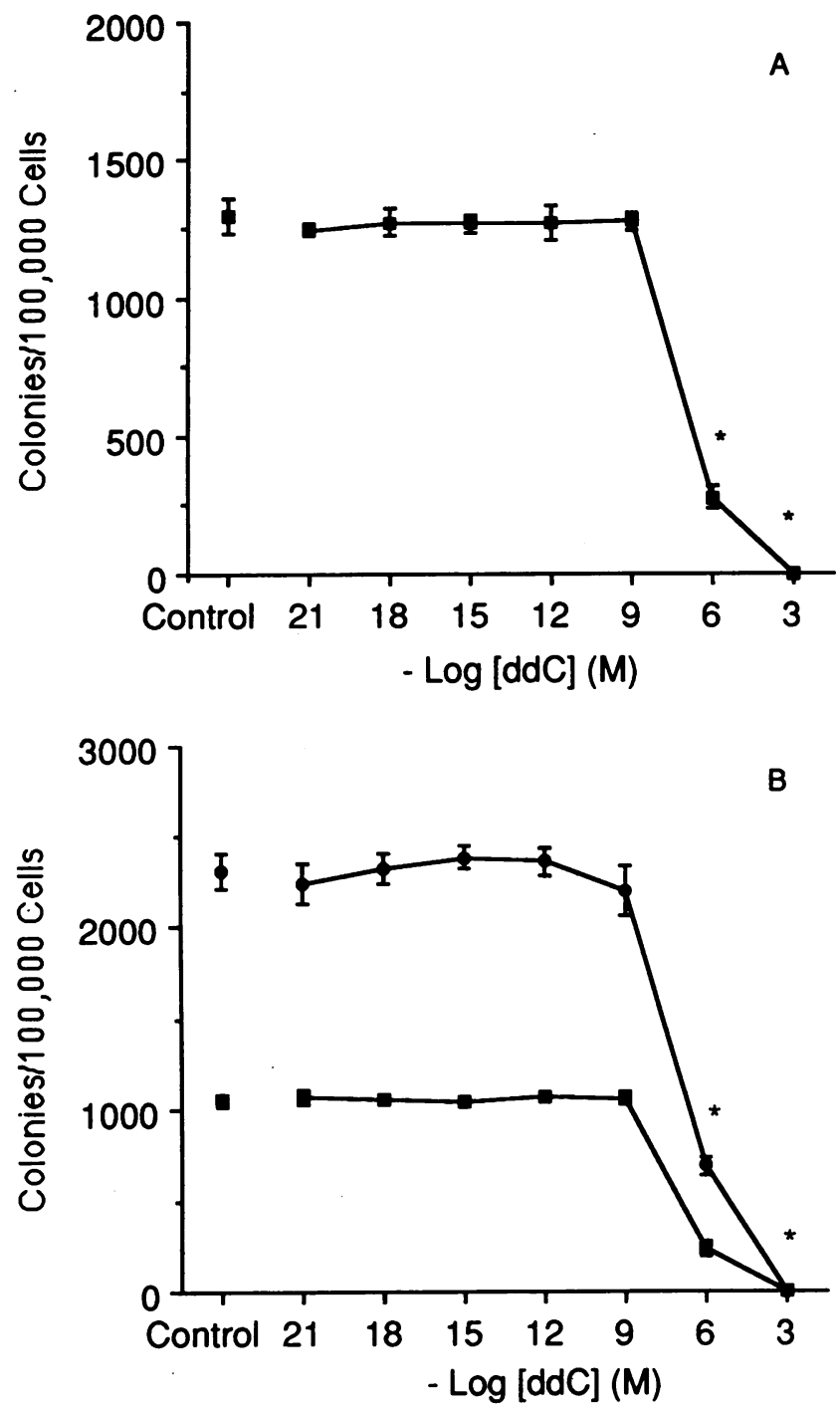

Figure 8. Effects of ddC on $(A)$ rIL-3 and $(B)$ rGM-CSF stimulated colony formation of $\mathrm{CD} 34$ purified (98\% positive) human BM with or without rSCF. ( $A$ ) ( $)$ IL-3 (10 ng/ml); $(B)(\square)$ rGM-CSF ( $5 \mathrm{ng} / \mathrm{ml})$; $(\bullet) \mathrm{rGM}-\mathrm{CSF}(5 \mathrm{ng} / \mathrm{ml})+\mathrm{rSCF}(25 \mathrm{ng} / \mathrm{ml})$. Error bars indicate 1 SEM for five cultures and are omitted when they are smaller than the symbol. * Significant decrease compared to controls not cultured with $\operatorname{ddC}(P \leq 0.05)$.

gests competition for uptake of the drug by BM cells not participating in clonogenic responses, and is consistent with an increased rate of conversion of $\mathrm{ddC}$ to 5 '-triphosphate in human relative to murine cells $(21)$.

\section{Discussion}

Many strains of laboratory mouse are particularly susceptible to the development of $\mathrm{T}$ cell lymphoma/leukemia, either spontaneously or as a result of chemical or radiation exposure (22, 23 ). In contrast, $T$ cell leukemias or lymphomas are relatively rare in human populations and have not been reported secondary to chemotherapy or chemical exposure $(24,25)$. A distinct subpopulation of SCF-dependent/IL-3 responsive HPC has been identified in the mouse that is uniquely susceptible to
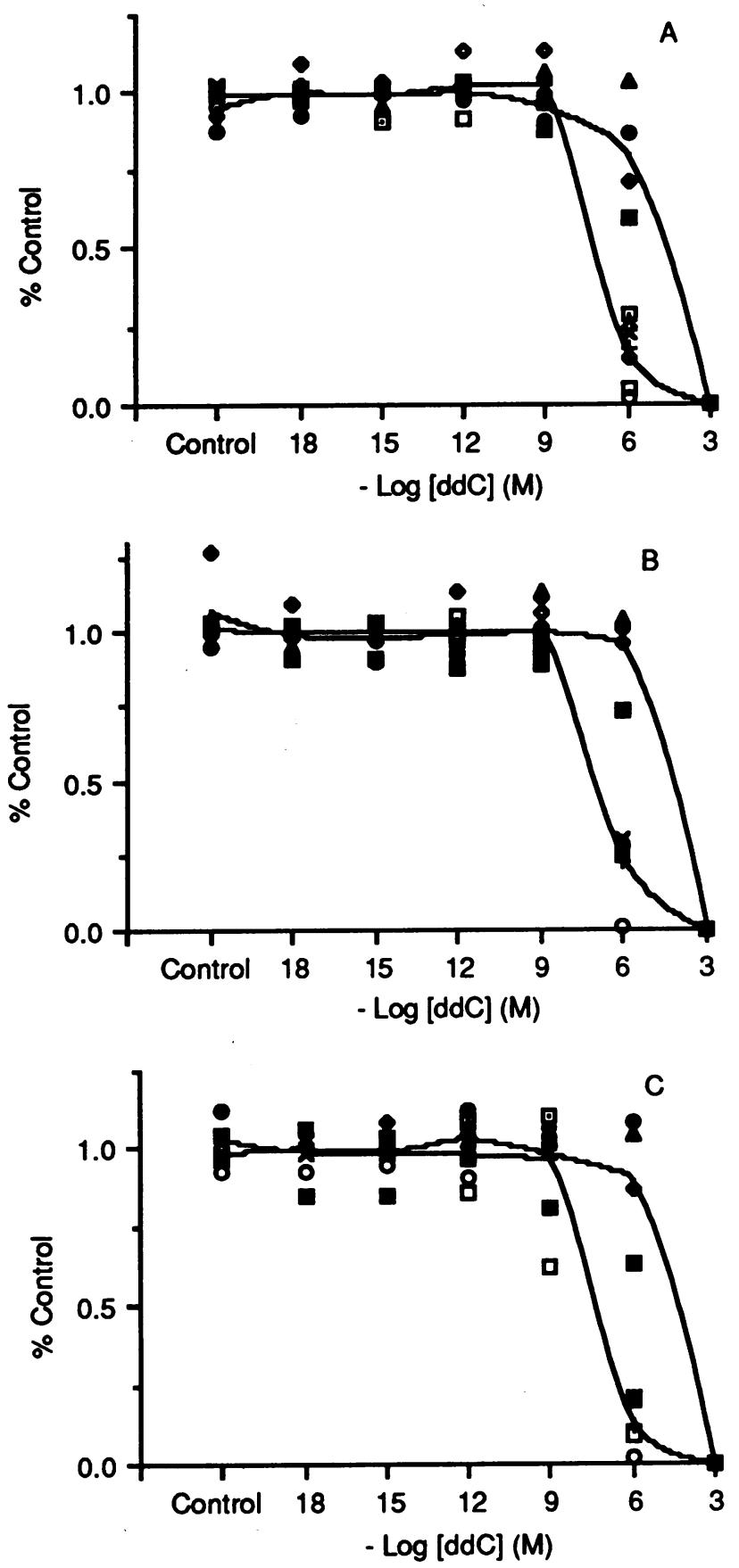

Figure 9. Comparison of $(A)$ rGM-CSF, $(B)$ rGM-CSF with rSCF, and (C) rIL-3-stimulated colony formation of human BM $(n=4)($ closed symbols) and CD34+ bone marrow cells $(n=7)$ (open symbols).

Values are normalized as percent of control and are derived from individual experiments conducted for each volunteer.

functional suppression by murine leukemogens, such as 1,3butadiene (13), $\gamma$-irradiation (Irons, R. D., S. C. Lee, and W. S. Stillman, manuscript in preparation) and now, ddC. This subpopulation has been demonstrated to be identical to that constitutively missing in mice bearing $\mathrm{W}$ or $\mathrm{Sl}$ mutations that spontaneously develop TL (13). The unique susceptibility of this subpopulation of cells to $\operatorname{ddC}\left(10^{-18} \mathrm{M}\right)$ and epoxybutene $\left(10^{-13} \mathrm{M}\right)(13)$ suggests that a specific signaling mechanism 
is involved in the targeting of these cells. Taken together, these results suggest that suppression of this subpopulation of primitive HPC represents the "preleukemic bone marrow lesion" common to chemical, radiation, and spontaneous models of murine leukemogenesis and provide evidence that targeting of this cell population is an early obligatory event in the development of murine TL.

There is growing evidence to suggest that species differences exist in the organization of the hematopoietic stem cell compartment, particularly with respect to the stage at which primitive HPC become restricted to a particular differentiation paradigm. In contrast to primitive murine HPC that require IL3 or SCF for survival, comparable human HPC appear to be supported in $\mathrm{G}_{\mathrm{O}}$ by IL-3 or GM-CSF but not SCF (26-28). It is apparent that these differences coincide with the observed susceptibility of an early SCF-responsive subpopulation of murine HPC, and that species differences in differentiation of early HPC play a major role in conferring susceptibility to TL development in the mouse. Moreover, because susceptibility of primitive HPC to drug suppression is observed only in the mouse, murine TL does not appear to be an appropriate biologic model for hazard identification in humans.

\section{Acknowledgments}

We thank Immunex Corp. for their generous gifts of human and murine rGM-CSF, rIL-3, and rSCF.

This work was supported by a grant from Hoffmann-La Roche Inc.

\section{References}

1. Waqar, M. A., M. J. Evans, K. F. Manly, R. G. Hughes, and J. A. Huberman. 1984. Effects of $2{ }^{\prime} 3^{\prime}$-dideoxynucleosides on mammalian cells and viruses. $J$. Cell. Physiol. 121:402-408.

2. Mitsuya, H., R. F. Jarrett, M. Matsukura, F. D. Veronese, A. L. DeVico, M. G. Sarngadharan, D. G. Johns, M. S. Reitz, and S. Broder. 1987. Long-term inhibition of human T-lymphotropic virus type III/lymphadenopathy-associated virus (human immunodeficiency virus) DNA synthesis and RNA expression in T cells protected by $2{ }^{\prime} 3$ '-dideoxynucleosides in vitro. Proc. Natl. Acad. Sci. USA. 84:2033-2037.

3. Richman, D. D., M. A. Fischl, M. H. Grieco, M. S. Gottlieb, P. A. Volberding, O. L. Laskin, J. M. Leedom, J. E. Groopman, D. Mildvan, M. S. Hirsch, G. G. Jackson, D. T. Durack, S. Nusinoff-Lehrman, and the AZT Collaborative Working Group. 1987. The toxicity of azidothymidine (AZT) in the treatment of patients with AIDS and AIDS-related complex. N. Engl. J. Med. 317:192-197.

4. Yarchoan, R., C. F. Perno, R. V. Thomas, R. W. Klecker, J-P. Allain, R. J. Wills, N. McAtee, M. A. Fischl, R. Dubinsky, M. C. McNeely et al. 1988. Phase I studies of 2'3'-dideoxycytidine in severe human immunodeficiency virus infection as a single agent and alternating with zidovudine (AZT). Lancet. 1:7681.

5. Rao, G., V. Sanders, M. Elwell, H. Giles, J. Heath, and C. Lindamood III. 1994. Toxicity and carcinogenicity of dideoxycytidine in mice. Tenth International Conference on AIDS. 1:207. (Abstr.)

6. Haran-Ghera, N. 1978. Spontaneous and induced preleukemia cells in C57BL/6 mice: brief communication. J. Natl. Cancer Inst. 60(3):707-711.

7. Haran-Ghera, N., and H. S. Kaplan. 1964. Significance of thymus and marrow injury in urethan leukemogenesis. Cancer Res. 24:1926-1931.
8. Kaplan, H. S. 1977. Interaction between radiation and viruses in the induction of murine thymic lymphomas and lymphatic leukemias. In Radiation-induced Leukemogenesis and Related Viruses. J. F. Duplan, editor. Elsevier/North-Holland Biomedical Press, New York. 1-18.

9. Irons, R. D., C. N. Smith, W. S. Stillman, R. S. Shah, W. H. Steinhagen, and L. J. Leiderman. 1986. Macrocytic-megaloblastic anemia in male B6C3F1 mice following chronic exposure to 1,3-butadiene. Toxicol. Appl. Pharmacol. 83:95-100.

10. Irons, R. D., C. N. Smith, W. S. Stillman, R. S. Shah, W. H. Steinhagen, and L. J. Leiderman. 1986. Macrocytic-megaloblastic anemia in male NIH swiss mice following repeated exposure to 1,3-butadiene. Toxicol. Appl. Pharmacol. 85:450-455.

11. Russell, E. S. 1979. Hereditary anemias of the mouse: a review for geneticists. Adv. Genet. 20:357-411.

12. Muto, M., E. Kubo, and T. Sado. 1985. Cellular events during radiationinduced thymic leukemogenesis in mice: abnormal $\mathrm{T}$ cell differentiation in the thymus and defect of thymocyte precursors in the bone marrow after split-dose irradiation. J. Immunol. 134:2026-2031.

13. Colagiovanni, D. B., W. S. Stillman, and R. D. Irons. 1993. Chemical suppression of a subpopulation of primitive hematopoietic progenitor cells: 1,3butadiene produces a hematopoietic defect similar to Steel or White Spotted mutations in mice. Proc. Natl. Acad. Sci. USA. 90:2803-2806.

14. Williams, D. E., J.'R. Eisenman, A. Baird, C. Rauch, K. Van Ness, C. J. March, L. S. Park, U. Martin, D. Y. Mochizuki, H. S. Boswell, G. S. Burgess, D. Cosman, and S. D. Lyman. 1990. Identification of a ligand for the c-kit protooncogene. Cell. 63:167-174.

15. Chabot, B., D. A. Stephenson, V. M. Chapman, P. Besmer, and A. Bernstein. 1988. The proto-oncogene c-kit encoding a transmembrane tyrosine kinase receptor maps to the mouse W locus. Nature (Lond.). 335 (1):88-89.

16. Witte, O. N. 1990. Steel locus defines new multipotent growth factor. Cell. 63:5-6.

17. Owen, P. E., J. R. Glaister, I. F. Gaunt, and D. H. Pullinger. 1987. Inhalation toxicity studies with 1,3 butadiene: III. Two year toxicity/carcinogenicity study in rats. Am. Ind. Hyg. Assoc. J. 48(5):407-13.

18. Owen, P. E., and J. R. Glaister. 1990. Inhalation toxicity and carcinogenicity of 1,3 butadiene in Sprague-Dawley rats: 1,3 butadiene life-span inhalation study in rats. Environ. Health Perspect. 86:19-25.

19. Upton, A. C. 1977. Experimental radiation-induced leukemia. In Radiation-Induced Leukemogenesis and Related Viruses. J. F. Duplan, editor. Elsevier/ North-Holland Biomedical Press, New York. 37-50.

20. Sutherland, H. J., P. M. Lansdorp, D. H. Henkelman, A. C. Eaves, and C. J. Eaves. 1990. Functional characterization of individual human hematopoietic stem cells cultured at limiting dilution on supportive marrow stromal layers. Proc. Natl. Acad. Sci. USA. 87:3584-3588.

21. Balzarini, J., R. Pauwels, M. Baba, P. Herdewijn, E. De Clercq, S. Broder, and D. G. Johns. 1988. The in vitro and in vivo anti-retrovirus activity, and intracellular metabolism of 3'-azido-2', 3'-dideoxythymidine and 2', 3'-dideoxycytidine are highly dependent on the cell species. Biochem. Pharmacol. 37:897903.

22. Kaplan, H. S. 1967. On the natural history of the murine leukemias: Presidential address. Cancer Res. 27(8):1325-1339.

23. Haran-Ghera, N., and A. Peled. 1979. Induction of leukemia in mice by irradiation and radiation leukemia virus variants. Adv. Cancer Res. 30:45-87.

24. Kyle, R. A., and M. A. Gertz. 1992. Second malignancies after chemotherapy. In The Chemotherapy Source Book. M. C. Perry, editor. Williams \& Wilkins, Baltimore. 689-702.

25. Dorr, F. A., and C. A. Coltman. 1985. Second cancers following antineoplastic therapy. In Current Problems in Cancer. R. C. Hickey, editor. Year Book Medical Publishers, Inc., 1-43.

26. Ogawa, M. 1993. Differentiation and proliferation of hematopoietic stem cells. Blood. 81:2844-2853.

27. Leary, A. G., H. Q. Zeng, S. C. Clark, and M. Ogawa. 1992. Growth factor requirements for survival in $\mathrm{G}_{\mathrm{O}}$ and entry into the cell cycle of primitive human hemopoietic progenitors. Proc. Natl. Acad. Sci. USA. 89:4013-4017.

28. Sutherland, H. J., D. E. Hogge, D. Cook, and C. J. Eaves. 1993. Alternative mechanisms with and without steel factor support primitive human hematopoiesis Blood. 81:1465-1470. 